\title{
HOW MYCORRHIZAS CAN HELP FORESTS TO COPE WITH ONGOING CLIMATE CHANGE?
}

\section{KAKO MIKORIZE MOGU POMOĆI ŠUMAMA DA SE NOSE S AKTUALNIM KLIMATSKIM PROMJENAMA}

\author{
Marina MILOVIĆ ${ }^{1}$, Marko KEBERT², Saša ORLOVIĆ ${ }^{3}$
}

\begin{abstract}
The ongoing climate change have multi-faceted effects not only on metabolism of plants, but also on the soil properties and mycorrhizal fungal community. Under climate change the stability of the entire forest ecosystems and the carbon balance depend to a large degree on the interactions between trees and mycorrhizal fungi. The main drivers of climate change are $\mathrm{CO}_{2}$ enrichment, temperature rise, altered precipitation patterns, increased $\mathrm{N}$ deposition, soil acidification and pollutants, ecosystem fragmentation and habitat loss, and biotic invasion. These drivers can impact mycorrhizal community directly and indirectly. We discussed the influence of each driver on mycorrhizal community and outlined how mycorrhizas play an important role in the resilience and recovery of forest ecosystems under climate change, by mitigating detrimental effects of $\mathrm{CO}_{2}$ enrichment, temperature rise, drought, lack of nutrients, soil acidification, pollutants, pests, and diseases. Conservation of the overall biodiversity in forest ecosystems as well as providing the most favourable conditions for the development of mycorrhizae can contribute to increasing the resilience of forest ecosystems to climate change.
\end{abstract}

KEY WORDS: mycorrhizal fungi, forest trees, colonisation, increase of $\mathrm{CO}_{2}$, drought

\section{CLIMATE CHANGE AND MYCORRHIZAE KLIMATSKE PROMJENE I MIKORIZE}

Global explosive growth of human population and overconsumption of fossil fuels in industrial era, caused exceeded emission of anthropogenic greenhouse gases. Their effects, together with effects of other anthropogenic drivers, are responsible for climate change which has become the greatest threat and challenge for natural ecosystems and their services. Climate change, characterized by a decrease in cold temperature extremes, an increase in warm temperature extremes, increased frequency and amplitude of heat waves, as well as altered precipitation patterns in a number of regions around the globe, has emerged as one of the most important issues of our time (IPCC, 2014).
Considering the fact that forest trees, through the process of photosynthesis, remove carbon dioxide $\left(\mathrm{CO}_{2}\right)$ from the atmosphere and store carbon in the form of tree biomass in the process called carbon sequestration, forests and climate change are intrinsically linked, since forests have a significant role in mitigation of climate change. On average two-thirds of carbon in forests are stored in soil, where a great deal of it is protected against turnover because it is captured in form of soil aggregates or chemical complexes (FAO, 2006).

However, climate change could detrimentally affect the growth and condition of forest trees. The severe impact of elevated air temperature and prolonged summer drought periods predicted by dramatic climate change scenarios, 
can lead not only to migrations (change of xeric distributional limits) of different forest tree species, but also to mortality of forest trees and decline of entire forests (Stojanović et al., 2013). Moreover, climate change can disturb the soil carbon balance by reducing carbon storage and by inducing a large positive feedback to atmospheric $\mathrm{CO}_{2}$ levels. Not only that disturbances could affect soil carbon storage and do harm to the trees, they could also accelerate nutrient cycling, alter microbial community structure, and change dynamics of soil food web. Carbon storage in soils involves complex interactions between plants and soil organisms and depends on the balance between carbon inputs through photosynthesis and outputs through respiration, which are both affected by climate change (Simard and Austin, 2010).

Under climate change the stability of the entire forest ecosystems and the carbon balance depend to a large degree on the interactions between trees and soil microorganisms, especially mycorrhizal fungi. Mycorrhizal fungi make mutualistic association with more than $90 \%$ of plant species and represent the key players in carbon dynamics and carbon fluxes among plants, soil and the atmosphere, due to their well branched system of hyphae which is used to obtain water and nutrients from the soil and deliver them to the host plant in exchange for photosynthetically produced carbohydrates (Smith and Read, 2008; Simard and Austin, 2010).

In temperate regions there are two dominant types of mycorrhizas. Ectomycorrhiza is formed mainly by ectomycorrhizal (ECM) fungi from phyla Basidiomycota and Ascomycota with trees and shrubs. Sporocarps of many ECM fungal species are edible, some even delicious and expensive (Katanić et al., 2017). An ECM root is characterized by three structural components: a mantle (or sheath), a Hartig net and an extraradical (extramatrical or external) mycelium. The mantle is a structure formed by fungal hyphae that enclose the rootlet. Function of Hartig net, a labyrinthine intercellular network, is exchange of nutrients between partners in ECM. Extraradical mycelium is an outwardly growing system of hyphal elements (hyphae, rhizomorphs and cystidia) which connect ECM fungus with both the soil and the sporocarps. This is an extensive system which increase the surface area of colonized root in the contact with soil, and it is active in absorption of nutrients and water (Smith and Read, 2008).

Arbuscular mycorrhiza is formed by arbuscular mycorrhizal (AM) fungi from phylum Glomeromycota with $80-90 \%$ of all plants but primarily with grasses and herbs. The name "arbuscular" is derived from characteristic three like structures, arbuscules which occur within cortical cells of plant and increase the contact area between symbionts. These structures are together with storage vesicles considered diagnostic for AM symbiosis (Smith and Read, 2008).
The main difference between these two types of mycorrhizae is that in ECM hyphae never enter plant cells while in AM fungal structures are mainly formed within cells of their host. AM fungi never produce mantle and their extraradical mycelium is not so complexly developed as in ECM fungi (Smith and Read, 2008). However, in both ECM and AM fungi extensive external mycelial networks can function in the colonization of new seedlings and transfer of carbon, nutrients or water between plants of the same or different species thus affecting plant and fungal community dynamics (Simard et al., 2002; Selosse et al., 2006; Smith and Read, 2008).

Considering the fact that the small and profuse hyphae have about 60 times more absorptive area than fine roots, during drought stress plants invest their photosynthetic carbon (4$20 \%$ ) in the development of hyphae, due to the higher efficacy of hyphae in provision of inaccessible water. Generally, as nutrient and water limitations increase, plants allocate more photosynthate to mycorrhizal hyphae to increase soil resource uptake (Simard et al., 2002; Smith and Read, 2008).

Although mycorrhizal fungi are not saprotrophic, in cases when amounts of plant photosynthates are low, some ECM fungi are prone to enzymatically decompose large organic molecules (e.g. proteins, chitin, pectin, hemicellulose, cellulose) as an alternative carbon and energy source, which is not specific for AM fungi (Talbot et al., 2008). On the other hand, arbuscular mycorrhizal fungi play important roles in promoting soil aggregation and soil carbon storage. Although AM hyphae turnover is short (lasts from days to a few months), AM fungi are able to deposit significant amounts of relatively recalcitrant carbon compounds such as chitin and glomalin. Glomalin binds small soil particles, promoting in that way aggregation and soil stability ( $\mathrm{Si}$ mard and Austin, 2010).

The ongoing climate change have multi-faceted effects not only on metabolism of plants, but also on the soil properties and all microorganisms including mycorrhizal fungal communities (Simard and Austin, 2010). Beside pivotal role of mycorrhizal fungi in linking aboveground and belowground components of forest ecosystems through common mycelial network, mycorrhizal fungi can improve plant tolerance to unfavorable abiotic stress factors such as heat, drought, salinity or presence of heavy metals, as well as boost plant immunity and increase resistance to pathogens and provide other ecosystem services (Smith and Read, 2008; Smith et al, 2010; French, 2017).

There are a lot of unfavorable factors and processes connected with climate change which influence forest ecosystems stability. According to Bellgard and Williams (2011) they are called the drivers of climate change and include: increasing $\mathrm{CO}_{2}$ concentration in the atmosphere, temperature rise, altered precipitation, increased $\mathrm{N}$ deposition, soil 
acidification and pollutants, ecosystem fragmentation and habitat loss, and biotic invasion. These factors impact soilrhizosphere, plant and fungal physiology and entire ecosystem directly and indirectly. Direct effects include changes in resources available to mycorrhizas and change in distribution of mycorrhizas. Indirect effects include changes in carbon allocation below ground to roots and mycorrhizas and changes in host plant species distribution (Bellgard and Williams, 2011).

Climate change ecological drivers can be divided according to the time frames related to the longevity of their influence on the planet and nature. Ecosystem fragmentation and habitat loss have immediate impacts (1-2 years); biotic invasions of exotic mycorrhizal fungi, plants and pests, diseases and other abiotic perturbations have short-term impacts (3-10 year); cumulative and additive effects of increased nitrogen $(\mathrm{N})$ and sulphur $(\mathrm{S})$ deposition, soil acidification and other pollutants have intermediate-term impacts (11-20 year); increase of $\mathrm{CO}_{2}$ concentration in the atmosphere and temperatures are destabilizing global rainfall patterns, soil properties and plant ecosystem resilience which have long-term impacts (21-50+ year) on the whole planet (Bellgard and Williams, 2011).

\section{Effects of increasing $\mathrm{CO}_{2}$ concentration in the atmosphere on mycorrhizae - Učinci povećanja koncentracije $\mathrm{CO}_{2}$ u atmosferi na mikorize}

Since the beginning of the Industrial Revolution (17501800), concentration of $\mathrm{CO}_{2}$ in the atmosphere has increased from $280 \mathrm{ppm}$ (parts per million) to approximately $400 \mathrm{ppm}$ at present. This $\mathrm{CO}_{2}$ increment is strongly correlated with increase in fossil fuels consumption and change in land use (Houghton, 1988; Bellgard and Williams, 2011).

Increase of atmospheric $\mathrm{CO}_{2}$ can affect mycorrhizal fungi indirectly through its impacts on host plants. Generally, plants can respond to this increase with higher productivity and their mycorrhizal symbionts can be proportionately larger (Staddon et al., 2002). Hence, higher plant productivity increases water and nutrient demands and increased photosynthesis enables plants to transfer more carbon belowground to roots and mycorrhizas (Pritchard et al., 2008), which stimulates mycorrhizal abundance and activity and favors the development of more extensive mycorrhizal networks with higher transfer capacity (Simard and Austin, 2010). However, under low $\mathrm{N}$ availability, increased $\mathrm{CO}_{2}$ stimulates aboveground and belowground biomass in ECM plants but has no effect in AM plants. So, only plants in association with ECM fungi can overcome nitrogen limitation (Terrer et al., 2016).

Increase of $\mathrm{CO}_{2}$ concentration in the atmosphere could cause alteration in mycorrhizal community structure as well. This change is dependent on the abilities of different fungal taxa to exploit carbon pools and nutrients or to adapt to the changing environment (Staddon et al., 2002; Simard and Austin, 2010). When elevated $\mathrm{CO}_{2}$ in the atmosphere increases belowground carbon allocation and stimulates nutrient deficiencies, exploration types of ECM fungi with hydrophobic rhizomorphs (medium- to long-distance exploration types) may be favoured because of their specific exploration strategies for accessing insoluble or stable nutrient patches (Hobbie and Agerer, 2010; Lilleskova et al., 2011). Since the effects of increased $\mathrm{CO}_{2}$ in the atmosphere on plants are species-specific, plant community structure is also changed, which will in turn cause alteration in the community of mycorrhizal fungi in environment with enriched $\mathrm{CO}_{2}$ (Staddon et al., 2002).

\section{Effects of increased air and soil temperature on mycorrhizae - Učinci povećanja temperature zraka i tla na mikorize}

The global surface temperature (calculated by averaging the temperature at the sea surface and air temperature over land) has increased over the last century by approx. $0.6^{\circ} \mathrm{C}$ (Bellgard and Williams, 2011). It was proved that temperature has direct effects on mycorrhiza. Namely, temperature affects the amount of resources available to mycorrhizas and distribution of mycorrhizas and their propagules. All organisms have temperature optimum because enzymatic activity is highly dependent on temperature. Since temperature affects plants it will also indirectly affect mycorrhizal fungi through its effects on their host plants (Staddon et al., 2002).

Generally, plant growth can be increased with soil temperature, but it can be decreased if nutrients or water in soil are deficient or reduced. On the other hand, warming is likely to increase respiration and decomposition rates and has the potential to change the availability of soil nutrients. To meet increasing demands for nutrients and water under increased temperature, mycorrhizal fungi will enhance their activity as the plants increase their productivity with soil temperature rise. In soil warming conditions, mycorrhizal fungal abundance has been shown to increase and community of ectomycorrhizal fungi has been recorded to change toward dominance of fungi with long-distance exploration capabilities that enable them to compete for scarce nutrients and contribute to soil carbon storage (Pendal et al., 2004; Simard and Austin, 2010).

\section{Effects of alteration in precipitation pattern on mycorrhizae - Učinci promjene distribucije oborina na mikorize}

It is certain that climate change is going to alter precipitation pattern locally, i.e. its intensity, frequency, duration, and amounts, which is likely to cause episodes of drought (Bellgard and Williams, 2011). Increased frequency and du- 
ration of drought episodes will negatively impact plants primarily by reducing plant biomass accumulation but also decreasing shoots height and survival (Vuksanović et al., 2019). Since low water content in soil influences nutrient availability and soil structure, mycorrhizal fungi may play significant positive roles in mitigation of water and nutrient deficiency (Smith et al., 2010).

Fungal hyphae are capable of exploring a larger soil volume than plant fine roots and therefore can mine available water from soil. Mycorrhizal plants can obtain nutrients from progressively narrow pores, as soil becomes drier or more compacted. (Smith et al., 2010). Furthermore, ECM fungi influence plant osmotic regulation and increase water-use efficiency because they increase mineral uptake and transfer and provide growth regulators (such as abscisic acid and cytokinins), that result in a reduction of water potential gradient between the soil and plant (Rudawska, 2007).

Water stress may influence the growth of root systems and mycorrhizas. Moderate drought stimulates mycorrhiza formation and maintenance through stimulation of newly discovered terpenoid group of plant hormones known as strigolactones (Bahadur et al., 2017), but if drought is severe the mycorrhizal fine roots may die (Rudawska, 2007). Drought might affect mycorrhiza ability to promote the drought tolerance of host plants (Gehring et al., 2017). However, mycorrhizal fungi differ in efficiency of waterregulation mechanisms and tolerance to water deficit, which depends on the properties of the fungal mycelium (Rudawska, 2007).

Studies of plant species dually colonized with both ECM and AM fungi (such as members of Salicaceae and Fagaceae) showed that ECM fungi are more sensitive to drought than AM fungi (Gehring et al., 2017). It was recorded that higher soil moisture level favoured colonization of ECM fungi in some members of genus Populus. (Lodge, 1989; Gehring et al., 2006). Furthermore, in multiclonal plantations it was noted that colonization of poplars (Populus spp.) with ECM fungi was significantly affected by site while colonization with AM fungi depended on genotype (Katanić et al., 2014). On the other hand, for some AM fungi it was observed that they are more responsive to temperature. Namely it was observed at the global scale that the intensity of plant root colonization by AM fungi was strongly related to warm-season temperature (Soudzilovskaia et al., 2015). Moreover, AM fungi predominate in more arid areas (Swaty et al., 2016), which indicates that they better tolerate drought. Drought tolerance in plants inoculated with AM fungi may be explained by increased production and accumulation of the sugar trehalose $\left(\mathrm{C}_{12} \mathrm{H}_{22} \mathrm{O}_{11}\right)$ in plant cells. Trehalose forms a gel-like substance which stabilizes lipid bilayers in cell organelles. Thus, organelles remain intact during desiccation and can return to life under favourable environmental conditions (French, 2017).
Also, drought might affect the activity, abundance and species composition of AM and ECM fungi. Studying the seasonal variation of the ECM community in mature poplar plantation, Katanić (2013) found lower number of ECM types in summer and autumn, when moisture content in soil was lower. Different species of ECM fungi respond differently to changes in soil moisture. For example, it was recorded that Cenococcum geophilum Fr. ectomycorrhizas responded to the drought induced stress better than Lactarius subdulcis (Pers.) Gray ectomycorrhizas (di Pietro, 2007). Moreover, it was observed that both fungal species and genotypes could respond differently to changes in soil moisture even if they are in association with the same species of host plant (Gehring et al., 2017). Although drought tends to decrease plant biomass, mycorrhizal fungi can mitigate that negative effect by improving plant productivity and growth (Kivlin et al., 2013).

\section{Effects of increased nitrogen deposition, soil} acidification and pollutants on mycorrhizae - Učinci povećanog taloženja dušika, zakiseljavanja tla i zagađivača na mikorize

Concentration of nutrients in natural ecosystems is increasing through anthropogenic nutrient deposition via fertilization and pollution, as well as through increased microbial decomposition induced by soil warming. Climate change can affect the nitrogen cycle, and soil warming can impact on the availability of soil nutrients as well (Simard and Austin, 2010). Wet and dry deposition of nitrogenous compounds $\left(\mathrm{NO}_{\mathrm{x}}\right.$ and $\left.\mathrm{NH}_{\mathrm{x}}\right)$ can become a dominant source of nitrate $\left(\mathrm{NO}_{3}^{-}\right.$) in many natural ecosystems (Bellgard and Williams, 2011). Moreover, inputs of atmospheric ions as nitrate $\left(\mathrm{NO}_{3}^{-}\right)$and sulphate $\left(\mathrm{SO}_{4}^{2-}\right)$ form acids that lower soil $\mathrm{pH}$ and consequently enhance mobility of many metals. According to some studies increased nitrogen deposition shown positive effects on aboveground plant productivity but negative impact on colonization of mycorrhizal fungi and the growth of the extraradical mycelium in both AM and ECM fungi. However, it was observed that generalist ECM fungal species which form a symbiosis with a wide range of plant species are less affected by increased $\mathrm{N}$ availability than specialist ECM species which form a symbiosis with a narrow range of plant species (Bellgard and Williams, 2011). If soil nutrient availability increases, plants invest less carbon into roots and development of mycorrhizas for nutrient uptake and allocate more carbon to aboveground parts.

The overall negative impact of increased $\mathrm{N}$ inputs on the ECM fungi might be also result of increased soil acidity ( $\mathrm{Si}$ mard and Austin, 2010; Bellgard and Williams, 2011). Different species of ECM fungi vary in their response to acidity of growth substrate. Although, most ECM fungi can grow on the $\mathrm{pH}$ range from 3.5 to 5.5 , many fungal species 
and strains are tolerant to high acidity and even some of them prefer lower $\mathrm{pH}$ (Rudawska, 2007). Thus, soil acidification can favour growth of ECM fungal species which are more tolerant to low $\mathrm{pH}$ in soil. If the individual species reproductive fitness is affected, a permanent shift in the diversity of ECM community will happen (Bellgard and Williams, 2011). At the end of $20^{\text {th }}$ century in different regions of Europe with increased soil acidification was observed a decline of sporocarps production and ECM diversity in forest communities (Arnolds, 1991).

It is also known that ECM and AM fungi prefer soils with different $\mathrm{pH}$ values. ECM fungi are associated with the dominant, mostly tree species, and occupy soils that have high accumulations of organic surface litter and thus often lower $\mathrm{pH}$ values. Furthermore, these mycorrhizal fungi do not invade soils of high $\mathrm{pH}$ value and high buffering capacity. Where such soils are converted to intensive crop agriculture, AM associations will become dominant and ECM will be excluded. On the other hand, AM associations dominate in soils with neutral to relatively high $\mathrm{pH}$, with high buffering capacity, which are immune to changes in the $\mathrm{pH}$ value. If these systems are disturbed, ECM fungi do not invade these soils, but AM fungi continue to dominate (Bellgard and Williams, 2011). Comparing the colonization level of roots with ECM, AM and dark septated endophytic fungi in poplars growing under different environmental conditions, at the site that was contaminated with pyrite tailings $\left(\mathrm{FeS}_{2}\right)$, heavy metals and had a low pH, Katanić et al. (2013) did not find structures of AM fungi while other fungal groups were present. These results are in acordance with previous results that AM fungi prefer soils with neutral or higher $\mathrm{pH}$ values.

Elevated concentrations of heavy metals in soil may have toxic effects on soil microorganisms and mycorrhizas of forest trees (Smith and Read, 2008). Heavy metals are accumulated in the organic layer of forest soils and can inhibit numerous soil processes which decrease decomposition and nutrient availability (Rudawska, 2007). Different species of mycorrhizal fungi and their strains are highly variable in the response to heavy metals in the growth medium (Rudawska, 2007). Heavy metals can detrimentally affect the formation and maintenance of ectomycorrhizas as well as its diversity on different tree species such as Populus spp. (Katanić et al., 2011; Katanić et al., 2015), Salix spp. (Regvar, 2010) and Picea spp. (Rudawska, 2007).

On the other hand, fungal partner in mycorrhizal symbiosis can prevent heavy metal transport from soil to the plant shoots. Response of mycorrhizas to heavy metals may be explained by various mechanisms of metal detoxification (Bellion et al., 2006; French, 2017). Metal ions may bind to compounds such as chitin, glomalin and melanin found in cell walls of fungal hyphae. The latter one is particularly well-known for its ability to protect fungi from a variety of unfavourable environmental conditions. Further, mycorrhizal fungi can stimulate the biosynthesis of chelating agents such as phytochelatins and metallothioneins to bind the metal ions and decrease their toxicity. Also, metal ions can be deposited throughout the wall, cytoplasm, and vacuole of fungal cell. However, mechanisms of detoxification of heavy metals inside the fungal mycelium require carbon. Mycorrhizae may also change metabolism of host plants in order to respond to metal toxicity (Bellion et al., 2006; Rudawska, 2007; French, 2017). It was observed that fungi which produce the largest quantity of extraradical mycelium are most efficient in accumulation of heavy metals and provide the best protection for host plants (Smith and Read, 2008; Bojarczuk and Kieliszewska-Rokicka, 2010).

Elevated concentrations of ozone $\left(\mathrm{O}_{3}\right)$ may have detrimental effects on mycorrhizal colonization and diversity. Tropospheric ozone has been recognized as a damaging agent to plants. It triggers numerous physiological changes in plant organism which lead to decreased carbon allocation below-ground, thus affecting roots and indirectly root symbionts such as mycorrhizal fungi (Cudlin et al. 2007). However, the sensitivity to ozone differs between tree species and clones, experimental growth conditions, and between the age-related physiological differences within the same species. Root growth reductions induced by ozone might make rhizosphere organisms more susceptible to drought or nutrient deficiency, as well (Cudlin et al. 2007).

The decreased growth of roots and mycorrhizas might be an early indicator of the damaging impacts of ozone in some tree species, occurring prior to visible responses of aboveground parts (Cudlin et al., 2007; Rudawska, 2007; Katanić et al., 2014).

\section{Effects of ecosystem fragmentation and habitat loss on mycorhizae - Učinci fragmentacije ekosustava i gubitka staništa na mikorize}

Climate change has a significant influence on the distribution of species as well. Fragmentation of natural land ecosystems is a result of colonization by humans and their domesticated animals. Habitat loss induced by the conversion of wildlands and forest ecosystems to agricultural lands threatens biodiversity and contributes to increasing of atmospheric $\mathrm{CO}_{2}$. Ecosystem fragmentation directly impacts dispersal of mycorrhizal fungi therefore affecting their community structure. Changes in the abundance and distribution of host plants significantly impact viability, productivity, and efficiency of fungal partner. This is particularly important for these mycorrhizal fungi that are obligatory dependent on their partner such as AM fungi (Bellgard and Williams, 2011). 
Effects of invasion of non-native mycorrhizal fungi, plants, pests, and diseases on mycorrhizae - Učinci invazije alohtonih mikoriznih gljiva, biljaka $i$ štetočina i bolesti na mikorize

The introduction and spread of non-native and invasive species represent a great risk to stability of forest ecosystems. Climate change, visible as change of climatic, atmospheric, and edaphic conditions, enables competitive and invasive non-native species to extend their present distribution ranges and reduce domestic biodiversity. Also, climate change causes shifts of plant species into previously marginal habitats which induce attendant shift in distribution and abundance of mycorrhizal fungi in association with these invading plant species. Many shifts in spatial distribution of plant species are accelerated by human mediation through transcontinental transport. Humans can also facilitate the introduction of non-native plant pests and non-native plant diseases into native forests and wildland ecosystems. Introduction of invasive mycorrhizal fungi, invasive nonnative plants and non-native plant diseases is detrimental to native host plants (Bellgard and Williams, 2011).

Researches have shown that inoculation of higher plant species with mycorrhizal fungi might reduce infections of pathogenic fungi and nematode infestations. This protection results from passive and active stimulation/modulation of plant secondary metabolism by AM fungi. Passively, AM fungal colonization stimulate host plants to produce and store highly potent defensive compounds such as alkaloids and terpenoids which are stored in trichomes and vacuoles and that can be released when attacked (Champagne and Boutry, 2016; French, 2017). On the other hand, fungal hyphae may react on pathogen in the surrounding environment and 'warn' host cells by producing special compounds which will be transmitted as signals throughout the host plant from cell to cell through the plasmodesmata (Zipfel and Oldroyd, 2017).

Mycorrhizal colonization triggers both plant's immune and defense systems, by triggering a primed state of plants resistance known as mycorrhiza-induced resistance (MIR). MIR improves holistic tolerance to attackers, either belowground by changing roots exudate metabolic composition in rhizosphere, or aboveground by alternation of volatile organic compounds (VOC) on shoot surface affecting allelopathic interaction by expressing repellent properties (López-Ráez et al., 2010). The phenomenon of priming could be defined as enhanced readiness of defense responses (Kim and Felton, 2013) and was described in plants with AM.

Different stimuli from pathogens, pests or chemicals can act as warning signals and trigger the establishment of priming. After perception of stimulus, changes may occur in the plant at the physiological, metabolic, transcriptional, and even epigenetic level (Avramidou, 2019). Upon subsequent pathogen attack primed plants display faster and/or stronger activation of various cellular defense responses to biotic or abiotic stress which leads to increased resistance and/or tolerance (Maunch-Mani et al., 2017). Best described and understood metabolic pathways induced by AM fungi priming signaling involve jasmonic acid (JA) and salicylic acid (SA) pathways that are in general mutually antagonistic (Jung et al., 2012). Furthermore, beneficial effects of AM fungi and increased resistance to pests could be broaden to transgenerational level, so it could be transferred to progeny, conferring better protection from pathogen attack and general fitness compared to descendants of unprimed plants by generating immunological memory (Pastor et al., 2012). Thus, priming of defense allows plants to boost their innate immune system and offers a long-term adaptation to disease-conducive conditions.

MIR can mitigate both abiotic and biotic stress factors and modulate and orchestrate entire plants response to environmental stresses to a certain extent. With regard to bioprotective, biofertilizer and priming properties of mycorrhizal symbiosis, Fester and Sawers (2011) consider that focus of the future research should be investigation of mycorrhization of the soil as an possible alternative to chemical fertilizers and pesticides in sustainable management and conservation of natural ecosystems.

\section{Role of mycorrhizas in forest stability under climate change - Uloga mikoriza u stabilnosti šuma u uvjetima klimatskih promjena}

Mycorrhizas are one of essential components of forest ecosystem stability. Their most important role in climate change conditions may be in stabilizing effects on forests trees that are under increasing environmental stress. The importance of mycorrhizal fungi in the ecosystem function is increasingly recognized, including the role of mycorrhizal networks in forest regeneration, succession, and resistance against different stress factors. Such networks which connect plants of the same or different species can affect the physiological and ecological processes of plants by facilitating interplant nutrient exchange, acting as inoculum reservoirs for seedlings and altering plant competitive abilities, but also play a pivotal role in orchestration of multitrophic aboveand belowground interactions (Selosse et al., 2006).

The most of young trees in forests are linked to large one, old and highly connected trees, which are important for forest regeneration. Moreover, the extensive mycorrhizal networks of large trees facilitate survival and growth of younger trees helping them to resist and cope with the stressful environmental conditions. Access to the mycorrhizal network not only improves seedling survival and physiology, but seedlings are colonized by a more complex fungal community and receive carbon, nutrients and water transferred from the older trees (Selosse et al., 2006; Simard and 
Austin, 2010). At sites without mycorrhizal networks and mycorrhizal fungal propagules, survival and growth of seedlings could be reduced and artificial inoculation with mycorrhizal fungi might be helpful. However, advantage should be given to autochthonous species and strains of mycorrhizal fungi (Katanić et al., 2009).

Forest management has an important role in forest stability under unfavourable conditions such as climate change. Forest practices that favour fungal taxa that produce extensive mycorrhizal networks in order to increase soil aggregation and connectivity, or species that produce decay-resistant compounds are very welcome. Under current climate change and loss of biodiversity, close-to nature forestry must be a priority. Furthermore, it is of great importance to harmonize the interests of forestry, agriculture, and environmental protection (Orlović et al., 2014).

\section{CONCLUSION ZAKLJUČAK}

Mycorrhizas have an important role in forest ecosystems stability under climate change, by mitigating detrimental effects of different unfavourable factors as increased $\mathrm{CO}_{2}$ in the atmosphere, temperature rise, drought, lack of nutrients, soil acidification, pollutants, pests, diseases, etc. Forest management in the context of climate change should be long term, sustainable, and based on natural principles.

\section{ACKNOWLEDGEMENT}

The study was financed by project 451-03-68/2020-14/ 200197 of the Ministry of Education, Science and Technological Development of the Republic of Serbia and by the Science Fund of the Republic of Serbia, PROMIS, GRANT No 6066613, MYCOCLIMART.

\section{REFERENCES}

\section{LITERATURA}

- Arnolds, E., 1991: Decline of ectomycorrhizal fungi in Europe, Agr Ecosyst Environ 35, 2-3: 209-244.

- Avramidou E.V., 2019: Epigenetics vs Genetics: Unravelling the importance beyond the gene in natural forest populations Topola/ Poplar, 203:31-35

- Bahadur, A., A Batool, F. Nasir, S. Jiang, Q. Mingsen, Q. Zhang. V. Feng, (2019). Mechanistic insights into arbuscular mycorrhizal fungi-mediated drought stress tolerance in plants, Int. J. Mol. Sci., 20(17), 4199.

- Bellgard, S.E., S. E. Williams, 2011: Response of Mycorrhizal Diversity to Current Climatic Changes, Diversity, 3, 8-90.

- Bellion, M., M. Courbot, C. Jacob, D. Blaudez, M. Chalot, 2006: Extracellular and cellular mechanisms sustaining metal tolerance in ectomycorrhizal fungi, FEMS Microbiol. Lett, 254: 173-181.

- Bojarczuk, K., B. Kieliszewska-Rokicka, 2010: Effect of Ectomycorrhiza on $\mathrm{Cu}$ and $\mathrm{Pb}$ accumulationin leaves and roots of Silver birch (Betula pendula Roth.) seedlings grown in metal-contaminated soil, Water Air Soil Pollut 207: 227-240.
- Champagne, A., M. Boutry, 2016: Proteomics of terpenoid biosynthesis and secretion in trichomes of higher plant species, Biochim. Biophys. Acta BBA 1864, 1039-1049.

- Cudlin, P., B. Kieliszewska-Rokicka, M. Rudawska, T. Grebenc, P. Alberton, T. Lehto, M. R. Akker, I. Børja, B. Konopka, T. Leski, H. Kraigher, T. W. Kuyper, 2007: Fine roots and ectomycorrhizas as indicators of environmental change, Plant. Biosystems 141 (3): 406- 425.

- di Pietro, M., J.-L. Churin, J. Garbaye, 2007: Differential ability of ectomycorrhizas to survive drying, Mycorrhiza (2007) 17:547550.

- FAO 2006: Global forest resources assessment 2005. FAO Forestry Paper 147, Rome.

- Fester, T., R. Sawers, 2011: Progess and challenges in agricultural applications of arbuscular mycorrhizal fungi, Crit rev plant sci, 30(5), 459-470.

- French, K.E., 2017: Engineering Mycorrhizal Symbioses to Alter Plant Metabolism and Improve Crop Health, Front. Microbiol. $8: 1403,1-8$

- Gehring, C.A., R.C. Mueller, T.G. Whitham, 2006: Environmental and genetic effects on the formation of ectomycorrhizal and arbuscular mycorrhizal associations in cottonwoods, Oecologia 149, 158-164.

- Gehring, C.A., R.L. Swaty, R.J. Deckert, 2017: Mycorrhizas, Drought, and Host-Plant Mortality, Mycorrhizal Mediation of Soil, Elsevier, 279-298, Amsterdam

- Hobbie, E.A., R. Agerer (2010): Nitrogen isotopes in ectomycorrhizal sporocarps correspond to belowground exploration types, Plant Soil 327, 71-83.

- Houghton, R.A., 1988: The global carbon cycle (letter to the editor). Science 241, 1736

- IPCC 2014: Climate Change 2014: Synthesis Report. Contribution of Working Groups I, II and III to the Fifth Assessment Report of the Intergovernmental Panel on Climate Change [Core Writing Team, R.K. Pachauri and L.A. Meyer (eds.)], IPCC, Geneva, Switzerland, 151 pp.May 14, 2015

- Jung SC, A. Martinez-Medina, J. A. Lopez-Raez, M. J. Pozo, 2012: Mycorrhiza-induced resistance and priming of plant defenses, J Chem Ecol. 38(6):651-664.

- Katanić M., 2013: Diversity of mycorrhizal fungi of poplars (Populus spp.) [in Serbian], Dissertation, Faculty of Sciences, Novi Sad

- Katanić M., A. Pilipović, B. Kovačević, S. Pekeč, Z. Novčić, 2014: Influence of genotype and environment on poplar roots colonization with mycorrhizal and endophytic fungi, [in Serbian], Topola/Poplar 193/194: 97-107

- Katanić M., M. Marković, P. Pap, M. Zlatković, S. Pekeč, B. Kovačević, 2017: Biology and cultivation of truffles in the world and in Serbia [in Serbian], Topola/Poplar, 199/200: 175-190.

- Katanić M., S. Orlović, Z. Galić, B. Kovačević, H. Kraigher, 2009: Mycorrhization of poplars (Populus sp.). Topola/Poplar 183/184, 95-113.

- Katanić, M., B. Kovačević, N. Glowska, E. Paoletti, S. Vasić, M Matavulj, H. Kraigher, 2013: Colonization of poplar roots with ectomycorrhizal, arbuscular mycorrhizal and dark septated endophytic fungi [in Serbian], Topola/Poplar 191/192: 17-29.

- Katanić, M., S. Orlović, T. Grebenc, B. Kovačević, M. Kebert, M. Matavulj, H. Kraigher, 2015: Mycorrhizal fungal community of poplars growing on pyrite tailings contaminated site near the river Timok, SEEFOR 6 (1):53-63

- Katanić, M., E. Paoletti, S. Orlović, T. Grebenc, H. Kraigher, 2014: Mycorrhizal status of an ozone sensitive poplar clone treated with the anti-ozonant ethylenediurea. Eur. J. For. Res, 133: 735-743. 
- Katanić M., S. Orlović, T. Grebenc, M. Bajc, Z. Galić, M. Kebert, H. Kraigher, 2011:

- Mycorrhizal fungy on poplars from a pyrite contaminated site In S. Orlović (ed), International Workshop „STREPOW“, Institute of Lowland Forestry and Environment, 313-320, Novi Sad

- Kim, J., G. W. Felton, 2013: Priming of antiherbivore defensive responses in plants, Insect Sci., 20(3), 273-285.

- Kivlin, S. N., S. M. Emery, J.A. Rudgers, 2013: Fungal symbionts alter plant responses to global change, Am. J. Bot. 100, 1445-1457.

- Lilleskova, E.A., E. A. Hobbie., T. R. Horton, 2011: Conservation of ectomycorrhizal fungi: exploring the linkages between functional and taxonomic responses to anthropogenic $\mathrm{N}$ deposition, Fungal ecol. 4 174 - 183.

- Lodge, D. J., 1989: The influence of soil moisture and flooding on formation of VA-endo- and ectomycorrhizae in Populus and Salix, Plant Soil 117: 243-253

- López-Ráez, J. A., A. Verhage., I. Fernández, J. M. García, C. Azcón-Aguilar, V. Flors, M. J. Pozo, 2010: Hormonal and transcriptional profiles highlight common and differential host responses to arbuscular mycorrhizal fungi and the regulation of the oxylipin pathway, J. Exp. Bot. 61(10), 2589-2601.

- Mauch-Mani B, I. Baccelli, E. Luna, V. Flors 2017: Defense Priming: An Adaptive Part of Induced Resistance, Annu Rev Plant Biol. 68:485-512.

- Orlović S., M. Drekić, B. Matović, L. Poljaković-Pajnik, M. Stevanov, D. Stojanović, S. Stojnić, 2014: Serbian Forestry - achievement of millenium goals in the era of climate change and globalization, Bulletin of the Faculty of Forestry: 89-112.

- Pastor, V., E. Luna, B. Mauch-Mani, J. Ton, V. Flors 2013: Primed plants do not forget, Environ Exp Bot, 94, 46-56.

- Pendall, E., S. Bridgham, P.J. Hanson, B. Hungate, D.W. Klicklighter, D.W. Johnson, B.E. Law, Y. Luo, J. P. Megonigal, M. Olsrud, M.G. Ryan, S. Wan, 2004: Belowground process responses to elevated $\mathrm{CO}_{2}$ and temperature: A discussion of observations, measurement methods, and models, New Phytol 62: 311-322.

- Pritchard, E. T. G., A. E. Strand, M.A. McCormack, M. A. Davis, A.C. Finzi, R.B., Jackson, M. Roser, H.H. Rogers, R. Oren, 2008: Fine root dynamics in a loblolly pine forest are influenced by freeair- $\mathrm{CO}_{2}$ - enrichment: a six-year-minirhizotron study, Glob Chang Biol 14: 1-15.

- Regvar M., M. Likar, A. Piltaver, N. Kugonič, J. E. Smith, 2010: Fungal community structure under goat willows (Salix caprea L.) growing at metal polluted site: the potential of screening in a model phytostabilisation study, Plant Soil 330: 345-356.
- Rudawska, M. L. 2007: Mycorrhiza, Biology and Ecology of Norway Spruce, Springer, 157-194, Dordrecht

- Selosse, M.-A., F. Richard, X. He, S.W. Simard, 2006: Mycorrhizal networks: les liaisons dangeureuses?, Trends Ecol. Evol 21: 621628.

- Simard, S., M. Austin, 2010: The Role of Mycorrhizas in Forest Soil Stability with Climate Change, Climate Change and Variability, IntechOpen, 275-302, Rijeka

- Simard, S.W., M.D. Jones, DM. Durall, 2002: Carbon and nutrient fluxes within and between mycorrhizal plants, Mycorrhizal Ecology, Springer-Verlag, 33-61, Heidelberg

- Smith S.E., D.J. Read, 2008: Mycorrhizal symbiosis, Third edition, ElsevierAcademic Press, 787pp., London

- Smith, S. E., E. Facelli, S. Pope, F.A. Smith, 2010: Plant performance in stressful environments: interpreting new and established knowledge of the roles of arbuscular mycorrhizas, Plant Soil 326:3-20.

- Soudzilovskaia, N.A., J.C. Douma, A.A. Akhmetzhanova, P.M.van Bodegom, W.K. Cornwell, E.J. Moens, K.K. Treseder, M. Tibbett, Y.P. Wang, J.H.C. Cornelissen, 2015: Global patterns of plant root colonization intensity by mycorrhizal fungi explained by climate and soil chemistry, Glob. Ecol. Biogeogr. 24, 371-382.

- Staddon P.L., A. Heinemeyer, A.H. Fitter, 2002: Mycorrhizas and global environmental change: research at different scales, Plant Soil 244: 253-261.

- Stojanović, D. B., T. Levanič, B. Matović, S. Orlović, 2015: Growth decrease and mortality of oak floodplain forests as a response to change of water regime and climate, Eur. J. For. Res. 134, 555-567.

- Swaty, R., H.M. Michael, R. Deckert, C.A. Gehring, 2016: Mapping the potential mycorrhizal associations of the conterminous United States of America, Fungal Ecol. 19.

- Talbot, J.M., S.D. Allison, K.K. Treseder, 2008: Decomposers in disguise: mycorrhizal fungi as regulators of soil carbon dynamics in ecosystems under global change, Funct. Ecol. 22: 955-963.

- Terrer, C., S. Vicca, B.A. Hungate, R.P. Phillips, I.C. Prentice, 2016: Mycorrhizal association as a primary control of the $\mathrm{CO}_{2}$ fertilization effect, Science 353, 72-74.

- Vuksanović V., B. Kovačević, S. Orlović, M. Kebert, M. Kovač, 2019: The influence of drought on growth and development of white poplar shoots in vitro, Topola/Poplar, 203:13-18

- Zipfel C, G.E. Oldroyd, 2017: Plant signalling in symbiosis and immunity, Nature 543(7645):328-336

\section{SAŽETAK}

Klimatske promjene koje su u tijeku, imaju višestruke učinke ne samo na metabolizam biljaka, već utječu i na svojstva tla i zajednicu mikoriznih gljiva. Pod utjecajem klimatskih promjena, stabilnost cjelokupnog šumskog ekosustava i ravnoteža ugljika ovise u velikoj meri o interakciji između drveća i mikoriznih gljiva. Pokretači klimatskih promjena su porast razine $\mathrm{CO}_{2}$, porast temperature, promjene distribucije oborina, povećano taloženje dušika, zakiseljavanje tla i zagađivanje polutantima, fragmentacija ekosustava, gubitak staništa i širenje invazivnih organizama. Pokretači klimatskih promjena mogu izravno i neizravno utjecati na zajednicu mikoriznih gljiva. $U$ radu je dan prikaz utjecaja svakog od navedenih pokretača na mikoriznu zajednicu i naglašeno da mikorize imaju važnu ulogu u otpornosti i oporavku šumskih ekosustava ublažavanjem štetnih učinaka porasta $\mathrm{CO}_{2}$, porasta temperature, suše, nedostatka hranjivih sastojaka, zakiseljavanja tla, porasta zagađivača u tlu, štetočina i bolesti. Očuvanje cjelokupne biološke raznolikosti u šumskim ekosustavima kao i osiguranje što povoljnijih uvjeta za razvoj mikorize može doprinijeti povećanju otpornosti šumskih ekosustava na klimatske promjene. 